\title{
BRACHIARIA DECUMBENS SUPRESSES THE INITIAL GROWTH OF COFFEA ARABICA
}

\author{
Guilherme Faus da Silva Dias ${ }^{1}$; Pedro Luís da Costa Aguiar Alves ${ }^{1 *}$; Tomás Carneiro de Souza \\ $\operatorname{Dias}^{1}$ \\ ${ }^{1}$ UNESP/FCAV - Depto. de Biologia Aplicada à Agropecuária, Via de Acesso Prof. Paulo Donato Castellane, s/n. - \\ 14884-900 - Jaboticabal, SP - Brasil. \\ *Corresponding author <plalves@fcav.unesp.br>
}

\begin{abstract}
Brachiaria decumbens is becoming one the most common weeds growing in young coffee orchards because, besides its fast growth and difficulty of control, new coffee orchards are usually established in pasture areas. In order to verify the effect of $B$. decumbens plant density on the early growth of coffee (Coffea arabica L. cv. Catuaí Amarelo), a competition experiment was conducted under semi-controlled humidity conditions. Soil collected in a Typic Haplustox was placed in $70 \mathrm{~L}$ asbestos cement boxes and one coffee seedling was planted in each box. The $B$. decumbens seedlings were transplanted to the boxes at the 24 leaf stage. Treatments consisted of $0,4,8,12,16,20,24,36,48$, and 60 weeds $\mathrm{m}^{-2}$. The experimental period started 120 days after transplanting and the experimental design was organized as completely randomized blocks, with four replicates. All coffee plant parameters evaluated were negatively affected by the interference. The most sensitive characteristics were leaf area $\left(41.8 \%\right.$ reduction with 8 plants $\mathrm{m}^{-2}$, reaching $68.7 \%$ at a density of 60 plants $\mathrm{m}^{-2}$ ). Therefore, at a density of 8 plants $\mathrm{m}^{-2}$ the reduction in leaf dry biomass was $41.4 \%$ compared with the check. At the density of 60 plants $\mathrm{m}^{-2}$ it was $72.8 \%$. B. decumbens, at a density of 8 or more plants $\mathrm{m}^{-2}$, suppressed coffee plants during a growth period of 120 days.
\end{abstract}

Key words: weed, coffee, competition, growth suppression

\section{BRACHIARIA DECUMBENS SUPRIME O CRESCIMENTO INICIAL DE COFFEA ARABICA}

\begin{abstract}
RESUMO: Brachiaria decumbens vem se tornando uma das plantas daninhas mais freqüentes na infestação de cafezais em formação, pois além de sua elevada agressividade e dificuldade de controle, está ocorrendo expansão das áreas cafeeiras para locais anteriormente ocupados por pastagens. Objetivou-se neste trabalho avaliar os efeitos desta planta daninha, em densidades crescentes, sobre o desenvolvimento inicial de mudas de café (Coffea arabica L. cv. Catuaí Amarelo). O experimento foi conduzido em condições semi-controladas, sem limitação de água. Uma muda de café foi transplantada em caixa de amianto com capacidade para $70 \mathrm{~L}$, preenchida com terra coletada da camada arável de um Latossolo Vermelho. Os tratamentos constaram de diferentes densidades de transplante de capim-braquiária, a saber: 0, 4, 8, 12, 16, 20, 24, 36, 48 e 60 plantas $\mathrm{m}^{-2}$. O ensaio foi conduzido por um período experimental de 120 dias após o plantio (DAP). Todas as características analisadas foram afetadas negativamente pela interferência da planta daninha, mas as que se mostraram mais sensíveis a essa interferência foram à área foliar e a biomassa seca das folhas. Houve redução de $41,8 \%$ na área foliar do cafeeiro quando conviveu com o capim-braquiária a partir da densidade de 8 plantas $\mathrm{m}^{-2}$, chegando a $68,7 \%$ na densidade de 60 plantas $\mathrm{m}^{-2}$. Também a partir da densidade de 8 plantas $\mathrm{m}^{-2}$, a redução na biomassa seca das folhas em relação à testemunha foi de $41,4 \%$ e na densidade de 60 plantas $\mathrm{m}^{-2}$ chegou a 72,8\%. Brachiaria decumbens, a partir da densidade de 8 plantas $\mathrm{m}^{-2}$, interfere negativamente sobre as mudas de café até os 120 DAP.

Palavras-chave: planta daninha, café, competição, supressão de crescimento
\end{abstract}

\section{INTRODUCTION}

Many factors can interfere with the growth development and production of the coffee plant (Friessleben et al., 1991). These factors can be physical (water supply, nutrients, soil $\mathrm{pH}$, etc.) or biological, that is, those that result from the interaction with live organisms (Pitelli \& Marchi, 1991). Prominent among these biological fac- tors is the interference of weeds on crops due to competition for light, nutrients, and water (Blanco, 1972). World losses of coffee due to the interference of weeds are around $15 \%$ of the total production (Bardner, 1978). Considering that the world coffee production is in the order of 120 million annual burlap bags (FNP Consultoria e Comércio, 2003), it is estimated that the losses related to weed interference can reach 18 million annual bags. 
The problems related to weed interference become worse when they are imposed in the beginning of the crop development (Blanco et al., 1982, Davies, 1987, Merino-Mejia et al., 1996). At this stage, the coffee plant exhibits a slow growth relative to the fast growth of weeds, so that competition for resources can be intense and coffee seedlings can be seriously affected by this competition (Friessleben et al., 1991). This problem becomes even more serious when the weed belongs to the Poaceae family, due to its great aggressiveness and fast growth (Kissmann, 1997). Among Poaceae weeds, Brachiaria decumbens Stapf. is becoming one the most common weeds growing in young coffee orchards because of its fast growth and difficulty of control in new coffee orchards that are established in pasture areas.

One of the factors that determines the magnitude of interference by weeds on crops is their density in the area (Bleasdale, 1960). The objective of this research was to evaluate the impact of different densities of Brachiaria decumbens on the initial growth and development of coffee seedlings (Coffea arabica L. cv. Catuaí Amarelo).

\section{MATERIAL AND METHODS}

This study was conducted under semi-controlled soil fertility and moisture conditions, during the winter season in the year of 1999, in Jaboticabal, SP, Brazil, at latitude $21^{\circ} 15^{\prime} 22^{\prime \prime} \mathrm{S}$ and longitude $48^{\circ} 18^{\prime} 58^{\prime \prime} \mathrm{W}$. The experiment was carried out in 75 -L boxes $(50 \times 50 \times 30 \mathrm{~cm})$. The substrate was collected from the top layer of a medium-textured, A moderate Typic Haplustox. The substrate properties were: $\mathrm{pH}\left(\mathrm{CaCl}_{2} 0.01 \mathrm{~mol} \mathrm{~L}^{-1}\right) 4.2 ; 6 \mathrm{~g} \mathrm{dm}^{-3}$ organic matter; $1 \mathrm{mg} \mathrm{dm}^{-3} \mathrm{P} ; \mathrm{K}, \mathrm{Ca}, \mathrm{Mg}, \mathrm{H}+\mathrm{Al}$ contents of $0.2,4,3,38 \mathrm{mmol}_{\mathrm{c}} \mathrm{dm}^{-3}$, respectively, and $\mathrm{V}(\%)=16$.

Forty-five days (d) before transplanting the coffee seedlings, phosphorus in the form of single superphosphate, lime, and an organic fertilizer were added to each box, following the usual recommendation by Graner \& Godoy Jr. (1967). At 30 and 60 d after seedling transplanting, nitrogen $(\mathrm{N})$ fertilizer in the form of urea was added in order to supply $2.0 \mathrm{~g}$ of $\mathrm{N}$ per box. Seeds of $B$. decumbens were sown in plastic boxes containing sand prior to transplanting to the final boxes. When the seedlings reached the 2 to 4 leaf stage, they were transplanted to the final boxes, with an excess of $30 \%$ in the number of individuals planted in each treatment, which were thinned out after one week in order to maintain the desired densities. The 'Coffea arabica cv. Catuaí Amarelo' coffee seedlings were 120 days old at transplanting time, with 29.1 $\mathrm{cm}$ in height, and had an average of 18 leaves. They were planted in the boxes $15 \mathrm{~d}$ after adjusting the $B$. decumbens seedling densities. A single plant was transplanted into each box. The plants did not suffer any water stress during the experimental period. Moisture in the substrate was maintained at an optimal level for plant development.
Treatments consisted of ten weed plant densities of $B$. decumbens: $(0,4,8,12,16,20,24,36,48$, and 60 weed plants $\mathrm{m}^{-2}$ ). The experimental design was organized as completely randomized blocks with four replicates.

Thirty days after transplanting the coffee seedlings, benomyl at $1 \mathrm{~g} \mathrm{~L}^{-1}$ water was applied for the preventive control of Cercospora coffeicola. This application is usually recommended for this crop. In addition, when the presence of ants (Acromyrmex sp. and Atta sp.) was observed in the experimental area, granular insecticides (sulfonamides) were applied. At the end of the experimental period ( $120 \mathrm{~d}$ after coffee seedling transplanting), their height (length of the main stem), number of leaves, leaf area, dry weight of leaves and stems were determined. The dry weight of leaves and stems of $B$. decumbens were also determined. Leaf area was measured using a leaf area meter (Li-Cor Instruments, model LI3000A) and the dry weights of the different parts of the plant were obtained after drying in a forced-air oven, at $70^{\circ} \mathrm{C}$ for $96 \mathrm{~h}$.

Data were subjected to regression analysis through the Table Curve 2D software (Jandel Scientific). The model presenting the best coefficient of determination was $\mathrm{y}=\mathrm{a}+\mathrm{b} \exp (-\mathrm{x} / \mathrm{c})$, where "a" refers to the minimum (or maximum asymptote), and practically stable value of the characteristic evaluated in the plants as density $(\mathrm{x})$ increases. The $1 / \mathrm{c}$ is the decrease or increase in the rate of the measured characteristic in response to $B$. decumbens density. Since the $B$. decumbens plant characteristics were fitted by an increasing exponential equation and coffee seedlings were fitted by a decreasing exponential equation, a linear correlation $(\mathrm{y}=\mathrm{a}+\mathrm{bx})$ between the characteristics of both species was determined with the same software, where "a" is the maximum value of " $y$ " as " $x$ " tends to zero and " $b$ " refers to the decreasing rate for the analyzed characteristic in the coffee plant in response to the $B$. decumbens characteristic.

\section{RESULTS AND DISCUSSION}

B. decumbens leaf area increased as plant density increased to approximately 20 plants $\mathrm{m}^{-2}$, and then stabilized at about $132,000 \mathrm{~cm}^{2}$ per box (Table 4). This is evident in the intra-specific competitive effect among $B$. decumbens plants, since at a density of 4 plants $\mathrm{m}^{-2}$ each weed plant presented an average leaf area of $224,000 \mathrm{~cm}^{2}$, whereas at 60 plants $\mathrm{m}^{-2}$, leaf area was $240,00 \mathrm{~cm}^{2}$ per plant. This corresponded to a decrease of $89 \%$ in leaf area, from the lowest to the highest density. The leaf area increase in response to plant density ( $x$ axis) followed an exponential equation, with a constant rate of $x / 6.46$ increment, reaching the maximum value of $130.7 \mathrm{~cm}^{2}$.

With reference to $B$. decumbens, the aboveground dry biomass increased up to 20 plants $\mathrm{m}^{-2}$. At this density, the value was stabilized (Table 4). At a density 
of 4 plants $\mathrm{m}^{-2}$, each plant accumulated $120 \mathrm{~g}$ of dry biomass on average, while at a density of 60 plants $\mathrm{m}^{-2}$, each plant accumulated $15 \mathrm{~g}$. This corresponded to a decrease of approximately $87 \%$. Dry biomass accumulation in response to density also followed an exponential equation, with a constant of $x / 8.72$ increment, reaching a maximum value of $850 \mathrm{~g}$. These results show the effect of intraspecific competition in $B$. decumbens plants. This exponential growth behavior is characterized by a convergence to the balance that occurred, in this experiment, with both dry biomass accumulation and leaf area (Cousens \& Mortimer, 1995). As infestation density increases, the relative importance of each plant decreases (Blanco, 1972); therefore, increasing the size of the population reduces the availability of resources for each individual.

At the density of 8 plants $\mathrm{m}^{-2}$, Brachiaria decumbens reduced coffee leaf area by $41.6 \%$ (Table 4 ). The reduction in coffee leaf area in response to weed density followed an exponential equation of the type $\mathrm{y}=\mathrm{a}+\mathrm{b} \exp (-\mathrm{x} / \mathrm{c})$, with a decreasing rate of $\mathrm{x} / 8.59$, until reaching the minimum and nearly constant value of 373 $\mathrm{cm}^{2}$ (Table 1). When comparing the effects of the extreme densities of $B$. decumbens $\left(0\right.$ and 60 plants $\mathrm{m}^{-2}$ ) for this coffee characteristic, a $68.7 \%$ reduction was observed.

The stem dry biomass of coffee plants was not significantly affected by the interference of $4 \mathrm{~B}$. decumbens plants $\mathrm{m}^{-2}$ (there was a reduction of only $1.4 \%$ in relation to the interference-free plant) (Table 4). However, at the density of 12 plants $\mathrm{m}^{-2}$ there was a reduction of $34.6 \%$ in stem dry weight. The reduction in coffee stem dry biomass in response to weed density followed an exponential equation of the type $\mathrm{y}=\mathrm{a}+\mathrm{b} \exp$ $(-x / c)$, with a decreasing rate of $x / 10.77$, and reached the minimum and nearly constant value of $2.64 \mathrm{~g}$. When the extreme densities of 0 and 60 plants $\mathrm{m}^{-2}$ were compared, a $51.6 \%$ reduction was observed.

There was a marked reduction in coffee leaf dry biomass caused by $B$. decumbens interference starting at the density of 8 plants $\mathrm{m}^{-2}$ (Table 4 ). At this density, the

Table 1 - Parameter values of the exponential equation $\mathrm{y}=\mathrm{a}+\mathrm{bexp}^{(-\mathrm{-} / \mathrm{c})}$ for each coffee plant characteristic evaluated.

\begin{tabular}{|c|c|c|c|c|}
\hline \multirow{2}{*}{$\begin{array}{l}\text { Coffee } \\
\text { characteristics }\end{array}$} & \multicolumn{4}{|c|}{ Parameters } \\
\hline & $a^{*}$ & $a+b^{* *}$ & {$[1-(\mathrm{a} / \mathrm{a}+\mathrm{b})]^{*} 100^{* * * *}$} & $1 / \mathrm{c}^{* * * * *}$ \\
\hline Leaf area & 373 & 1191 & 68.6 & 0.116 \\
\hline $\begin{array}{l}\mathrm{DW}^{1} \\
\text { above-ground }\end{array}$ & 5.09 & 14.44 & 64.7 & 0.101 \\
\hline DW leaves & 2.44 & 9.00 & 72.8 & 0.105 \\
\hline DW stem & 2.64 & 5.45 & 51.5 & 0.093 \\
\hline Leaf number & 39 & 74.5 & 47.0 & 0.107 \\
\hline
\end{tabular}

reduction in leaf dry biomass in relation to interferencefree plants was $41.4 \%$. The reduction in leaf dry biomass in response to weed density was also exponential, with a decreasing rate of $x / 9.52$; the minimum value at which this parameter was stabilized was $2.44 \mathrm{~g}$. At the highest density $\left(60\right.$ plants $\left.\mathrm{m}^{-2}\right)$, the reduction in relation to the density of 0 plants $\mathrm{m}^{-2}$ was $72.8 \%$.

With regard to the above-ground dry biomass of coffee (Table 4), a pronounced reduction was also noticed starting at the density of 8 plants $\mathrm{m}^{-2}$, for which there was a reduction of $36 \%$. The reduction in coffee total dry biomass, in response to competition from the noxious plant was exponential, with a decreasing rate of $\mathrm{x} / 9.86$; a minimum and nearly constant value of $5.09 \mathrm{~g}$ was reached. When the effects of extreme weed densities $(0$ and 60 plants $\mathrm{m}^{-2}$ ) were compared for this coffee plant characteristic, a reduction of $64.7 \%$ was observed.

As for the number of coffee leaves, $B$. decumbens at the density of 4 plants $\mathrm{m}^{-2}$ caused no detrimental effects (Table 4). Starting at the density of 8 plants $\mathrm{m}^{-2}$ there was a reduction of $27.15 \%$ in the number of coffee leaves caused by weed interference. This reduction followed an exponential equation of the type $\mathrm{y}=\mathrm{a}+\mathrm{b} \exp (-\mathrm{x} / \mathrm{c})$, with a decreasing rate of $x / 9.31$ and it reached a minimum and nearly constant value of 35 leaves. When the effects of extreme $B$. decumbens densities $\left(0\right.$ and 60 plants $\left.\mathrm{m}^{-2}\right)$ on this coffee plant characteristic were compared, a reduction of $47.1 \%$ was observed.

The 120-day-old coffee seedlings were severely affected by $B$. decumbens interference. This interference increased as weed density rose up to 12 plants per square meter, after which the effect was stabilized. The increase in weed density increased the number of individuals that utilize the same natural resources and, therefore, a more intense competition between coffee and weeds occurred. This fact confirms the results obtained by Zakharenk (1969) in that yield of a crop decreases as the number of weeds competing for the same resources increases. However, starting at the density of $12 \mathrm{~B}$. decumbens plants $\mathrm{m}^{-2}$, the interference effects between the weeds increased, which probably lessened their effects on the crop.

Analyzing the evaluated characteristics and the parameters of each exponential equation, especially the variation between maximum and minimum and the decreasing rate (Table 4), the two most affected characteristics were leaf area and leaf dry weight. Studying the interference of weeds in eucalyptus, which shows a behavior similar to coffee as a perennial crop, Pitelli \& Marchi (1991) observed that the eucalyptus plant under intense weed infestation stops producing branches and tends to lose leaves at the base of the stem. This fact was observed in the coffee plants, whose basal (larger) leaves were lost, and the new leaves emitted at the plant's apex were smaller, explaining why the greatest reductions in coffee characteristics were in leaf dry weight and leaf area. 
Dinardo (1996) and Toledo et al. (2001), studying the effect of different densities of $B$. decumbens and Paniccum maximum on the initial growth of Eucalyptus grandis seedlings, observed that when eucalyptus plants were under $B$. decumbens interference the most sensitive characteristics to this interference were dry weight of branches, number of leaves, and leaf area. When the plants were under Panicum maximum interference, the most sensitive characteristics were dry weight of branches, roots, leaves, and stem.

In coffee plants, Dias et al. (2001) observed that Commelina benghalensis at a density of 8 plants $\mathrm{m}^{-2}$ or more, reduced plant growth, reaching a 59\% reduction in leaf dry matter and $56 \%$ in leaf area, which were also the most sensitivy characteristics, at a density of 36 plants $\mathrm{m}^{-2}$. These results confirm the fact observed in this experiment, that characteristics related to the crop's leaves are the most sensitive to weed competition interference. This result is probably due to the fact that leaves in a growing seedling are the most demanding sink for nutrients which will be needed to promote vegetative growth. The senescence of lower leaves could be caused by stress, resulting in mobilization of their nutrients to upper, growing leaves. Lemes et al. (2003) verified that the interference of a weed community with prevalence of Digitaria horizontalis, Parthenium hysterophorus, Commelina benghalensis, and Eleusine indica, at a density of 130 plants $\mathrm{m}^{-2}$ and dry weight of $800 \mathrm{~g} \mathrm{~m}^{-2}$ reduced coffee yield by 53 and $47 \%$, in the first and second years, respectively. The period before weed interference in the first year was $86 \mathrm{~d}$, and in the second year it was $138 \mathrm{~d}$. Dias et al. (2003a), working with a weed community with prevalence of $C$. benghalensis, found this period to be 15 $\mathrm{d}$ under winter conditions, and $22 \mathrm{~d}$ under summer conditions. The total period for the prevention of weed interference was 88 and $38 \mathrm{~d}$, respectively.

In another paper, Dias et al. (2003b) verified that weed control applied in strips within the row promoted better yield and plant development results than when weeds were controlled between the crop rows. When the control was done in the row, there were no differences in growth, yield, and stem diameter between control strips with 80 and $250 \mathrm{~cm}$. In the weed control treatment between rows, coffee plants that remained in weed-free areas showed better development than the others.

When weed dry weight accumulation and leaf area as a function of planting density were compared with the effects of weed interference on coffee growth, the behavior (mathematical expression) was similar, but inverse. Approximately in the linear phase of the exponential growth of weeds there was a linear reduction in coffee growth, allowing the establishment of correlations between them.

In the correlation between coffee plant characteristics evaluated and $B$. decumbens dry weight and leaf area, a linear equation was obtained, whose parameters are in Tables 2 and 3, respectively. From the analysis based on the determination coefficients, the characteristics with the highest values were leaf dry matter, leaf area, and above-ground dry matter, for the correlation done with either $B$. decumbens leaf area or dry matter. The smallest values were found for the correlation of number of leaves and stem dry matter, demonstrating that the correlation was not as good for these characteristics. When coffee characteristics were correlated with $B$. decumbens dry matter, the determination coefficients were always greater than those from correlations involving $B$. decumbens leaf area, indicating a better fit of the former in relation to the latter.

The analysis of the calculated slope coefficients (b) indicated that the decreasing rate was more pronounced for leaf area and number of leaves, and less marked for stem dry matter, indicating that this last characteristic was less sensitive to weed interference. The slope coefficients obtained from the correlations with $B$. decumbens dry matter were greater than those obtained in correlations with leaf area. This could imply that the negative effects of the weed on coffee were caused more because of dry matter accumulation than because of leaf area increases. However, further research is needed to confirm this tentative conclusion.

Table 2 - Values of $a, b$ and $R^{2}$ in linear equations $(y=a+b x)$ obtained from the correlation between evaluated coffee characteristics and above-ground dry biomass of Brachiaria decumbens.

\begin{tabular}{lrcc}
\hline \multirow{2}{*}{ Coffee characteristics } & \multicolumn{3}{c}{ Parameters } \\
\cline { 2 - 4 } & \multicolumn{1}{c}{$\mathrm{a}$} & $\mathrm{b}$ & $\mathrm{R}^{2^{*}}$ \\
\hline Leaf area & 1201.3181 & -0.9570 & 0.8553 \\
DW $^{1}$ above-ground & 14.7674 & -0.0109 & 0.8320 \\
DW leaves & 9.2420 & -0.0077 & 0.8756 \\
DW stem & 5.5372 & -0.0032 & 0.6984 \\
Leaf number & 74.0086 & -0.0388 & 0.6392 \\
\hline
\end{tabular}

${ }^{1} \mathrm{DW}=$ Dry weight, *Determination coefficient

Table 3 - Values of $a, b$ e $R^{2}$ in linear equations $(y=a+b x)$ obtained from the correlation of evaluated coffee characteristics and leaf area of Brachiaria decumbens.

\begin{tabular}{lrcc}
\hline \multirow{2}{*}{ Coffee characteristics } & \multicolumn{3}{c}{ Parameters } \\
\cline { 2 - 4 } & \multicolumn{1}{c}{$\mathrm{a}$} & $\mathrm{b}$ & $\mathrm{R}^{2 *}$ \\
\hline Leaf area & 1208.9906 & -0.0059 & 0.7976 \\
DW $^{1}$ above-ground & 14.8548 & -0.00007 & 0.7758 \\
DW leaves & 9.3210 & -0.00005 & 0.8221 \\
DW stem & 5.5456 & -0.00002 & 0.6405 \\
Leaf number & 73.8522 & -0.0002 & 0.5742 \\
\hline
\end{tabular}

${ }^{1} \mathrm{DW}=$ Dry weight, $*$ Determination coefficient. 
Table 4 - Effect of weed plant density on weed leaf area, weed dry biomass weight, coffee plant leaf area, coffee stem dry weight, coffee leaves dry weight, total coffee dry weight, and number of coffee leaves.

\begin{tabular}{|c|c|c|c|c|c|c|c|}
\hline \multirow{2}{*}{$\begin{array}{l}\text { Weed plant } \\
\text { density }\end{array}$} & \multirow{2}{*}{$\begin{array}{l}\text { Weed leaf } \\
\text { area }\end{array}$} & \multirow{2}{*}{$\begin{array}{l}\text { Weed dry } \\
\text { weight }\end{array}$} & \multicolumn{5}{|c|}{ Coffee Plant } \\
\hline & & & $\begin{array}{c}\text { Leaf } \\
\text { area } \\
\end{array}$ & $\begin{array}{c}\text { Dry weight } \\
\text { stem }\end{array}$ & $\begin{array}{c}\text { Dry weight } \\
\text { leaves }\end{array}$ & $\begin{array}{c}\text { Total dry } \\
\text { weight }\end{array}$ & $\begin{array}{c}\text { Leaf number } \\
\text { coffee }\end{array}$ \\
\hline $\mathrm{n}^{\circ} \mathrm{m}^{-2}$ & $\mathrm{~cm}^{2} 0.25 \mathrm{~m}^{-2}$ & g $0.25^{-2}$ & $\mathrm{~cm}^{2} 0.25 \mathrm{~m}^{-2}$ & - & $-\mathrm{g} 0.25 \mathrm{~m}^{-2}$ & - & \\
\hline 0 & $0 \pm 0 *$ & $0 \pm 0$ & $1159 \pm 311$ & $5.3 \pm 1.3$ & $8.7 \pm 2.5$ & $14.0 \pm 3.0$ & $70 \pm 13$ \\
\hline 4 & $89030 \pm 19452$ & $473.2 \pm 89.9$ & $991 \pm 218$ & $5.2 \pm 0.9$ & $7.5 \pm 2.0$ & $12.6 \pm 3.3$ & $74 \pm 9$ \\
\hline 8 & $94256 \pm 27397$ & $529.2 \pm 123.8$ & $655 \pm 53$ & $4.0 \pm 0.8$ & $5.0 \pm 0.6$ & $9.0 \pm 1.4$ & $52 \pm 3$ \\
\hline 12 & $89965 \pm 14658$ & $566.2 \pm 100.9$ & $491 \pm 144$ & $2.9 \pm 0.9$ & $3.8 \pm 1.0$ & $6.8 \pm 2.0$ & $42 \pm 15$ \\
\hline 16 & $110895 \pm 15342$ & $685.5 \pm 107.3$ & $483 \pm 44$ & $2.9 \pm 0.3$ & $3.4 \pm 0.3$ & $6.2 \pm 0.5$ & $40 \pm 3$ \\
\hline 20 & $126777 \pm 17534$ & $760.4 \pm 108.2$ & $486 \pm 46$ & $3.3 \pm 0.7$ & $3.4 \pm 0.4$ & $6.6 \pm 1.0$ & $45 \pm 3$ \\
\hline 24 & $120023 \pm 7808$ & $778.9 \pm 34.8$ & $471 \pm 42$ & $3.6 \pm 0.3$ & $3.4 \pm 0.2$ & $6.9 \pm 0.5$ & $48 \pm 8$ \\
\hline 36 & $132856 \pm 17945$ & $805.0 \pm 104.6$ & $445 \pm 57$ & $2.7 \pm 0.5$ & $3.5 \pm 0.6$ & $5.9 \pm 0.9$ & $43 \pm 6$ \\
\hline 48 & $133520 \pm 25890$ & $850.2 \pm 107.6$ & $390 \pm 77$ & $2.8 \pm 0.6$ & $3.0 \pm 0.7$ & $5.5 \pm 1.2$ & $42 \pm 6$ \\
\hline 60 & $143206 \pm 18904$ & $905.1 \pm 114.8$ & $292 \pm 43$ & $2.4 \pm 0.1$ & $1.9 \pm 0.3$ & $4.1 \pm 0.5$ & $35 \pm 6$ \\
\hline
\end{tabular}

$*$ Mean $\pm \mathrm{S}$.

\section{REFERENCES}

BARDNER, R. Pest control in coffee. Pesticide Science, v.9, p.458-464, 1978.

BLANCO, H.G. A importância dos estudos ecológicos nos programas de controle de plantas daninhas. Biológico, v.38, p.343-350, 1972.

BLANCO, H.G.; OLIVEIRA, D.A.; PUPO, E.I.H. Período de competição de uma comunidade natural de mato em uma cultura de café em formação. Biológico, v.48, p.9-20, 1982

BLEASDALE, J.K.A. Studies on plant competition. In: HARPER, J.L. (Ed.) The Biology of weeds. Oxford: Blackwell Scientific Publications, 1960. p.133-142.

COUSENS, R.; MORTIMER, M. Dynamics of weed populations. Cambridge: Cambridge University Press, 1995.

DAVIES, R.J. Tree and weeds: Control for successful tree establishment. London: HMSO, 1987.

DIAS, T.C.S.; ALVES, P.L.C.A.; BRENDOLAN, R.A.; OLIVEIRA, G.C. Efeito da densidade de trapoeraba sobre o crescimento inicial do cafeeiro. In: CONGRESSO DE INICIAÇÃO CIENTÍFICA DA UNESP, 13, Bauru, 2001. Anais. Bauru: UNESP, 2001. p.271.

DIAS, T.C.S.; ALVES, P.L.C.A.; OLIVEIRA, G.C. Efeito de períodos de controle e de convivência de plantas de trapoeraba (Commelina benghalensis) sobre o crescimento inicial do cafeeiro (Coffea arabica L.) In: CONGRESO LATINOAMERICANO DE MALEZAS (ALAM), 16., Manzilo, 2003. Resumos. Manzilo: Universidad de Colima, 2003a. p.446.

DIAS, T.C.S.; ALVES, P.L.C.A.; LEMES, L.N. Efeito da área de interferência das plantas daninhas sobre a produção de Coffea arabica L. In: CONGRESO LATINOAMERICANO DE MALEZAS (ALAM), 16., Manzilo, 2003. Resumos. Manzilo: Universidad de Colima, 2003b. p.447.

DINARDO, W. Efeito da densidade de plantas de Brachiaria decumbens Stapf. e Panicum maximum Jacq. sobre o crescimento inicial de mudas de Eucalyptus grandis W. Hill ex Maiden. Jaboticabal: UNESP/FCAV, 1996. (Trabalho de graduação). 77p.
FNP CONSUltoria E COMÉRCiO. AgrianuAL: Anuário da agricultura brasileira. São Paulo, 2003. p.249-262.

FRIESSLEBEN, U.; POHLAN, J.; FRANKE, G. The response of Coffea arabica L. to weed competition. Café Cacao Thé, v.25, p.15-20, 1991.

GRANER, E.A.; GODOY JR., C. Manual do cafeicultor. Piracicaba: ESALQ, 1967

KISSMANN, K.G. Plantas infestantes e nocivas. São Paulo: BASF Brasileira, 1997.

LEMES, L.N.; ALVES, P.L.C.A.; DIAS, T.C.S. Determinação do período anterior à interferência das plantas daninhas na produção do cafeeiro "Mundo Novo" recepado. In: CONGRESO LATINOAMERICANO DE MALEZAS (ALAM), 16., Manzilo, 2003. Resumos. Manzilo: Universidad de Colima, 2003. p. 463.

MERINO-MEJIA, C.I.; RAMIREZ-AMADOR, R.; IBARRA, E.L. Estúdio sobre períodos de competência interespecífica maleza - cafeto. In: SIMPÓSIO SOBRE CAFEICULTURA LATINOAMERICANA, 17., E Salvador, 1995. Procedings. El Salvador, 1996. p.15-16.

PITELLI, R.A.; MARCHI, S.R. Interferência das plantas invasoras nas áreas de reflorestamento. In: SEMINÁRIO TÉCNICO SOBRE PLANTAS DANINHAS E USO DE HERBICIDAS EM REFLORESTAMENTO, 3., Belo Horizonte, 1991. Procedings. Belo Horizonte, 1991. p.1-11.

TOLEDO, R.E.B.; DINARDO, W.; BEZUTTE, A.J.; ALVES, P.L.C.A.; PITELLI, R.A. Efeito da densidade de plantas de Brachiaria decumbens Stapf sobre o crescimento inicial de mudas de Eucalyptus grandis W. Hill ex. Maiden. Scientia Forestalis, v.60, p.46-52, 2001.

ZAKHARENK, V.A. Investigating the competitive ability of weeds and crop plants in relation to herbicide application. Weed Abstracts, v.18, p.1271, 1969.

Received October 17, 2003

Accepted September 13, 2004 